\title{
Developments in Fish Food Technology - Implications for Capture Fisheries
}

\author{
Grimur Valdimarsson \\ Icelandic Fisheries Laboratories \\ Skulagata 4, 101 Reykjavik, Iceland
}

\begin{abstract}
It is estimated that the marine fisheries are presently at its full potential, i.e. 82-83 million tons per year. As wild fish select their own food they provide the most natural source of animal protein available to mankind. Yet, there is significant potential in better utilization of the marine resources. One third of the ocean catch, or 27 million tons, is discarded at sea every year, fish material that could be processed in various ways. Also, the processing industry can improve yields, use more of the "fish waste" not to mention improving quality of products. The fish processing industry is unique in the way how its raw material is obtained. In most cases fishermen compete with one another to get as much fish as possible from a common source and the raw material is free of charge. This leads to a "quantity mentality" that impairs development of the industry in terms of utilisation and quality of products. The Icelandic economy is highly dependent on fisheries as some $54 \%$ of her currency earnings come from fish exports even though only $11 \%$ of the workforce is engaged in fisheries and fish processing. In 1984 all the major fish stocks were subjected to individual quotas and in 1990 the quotas were made transferable between vessels. Today over $90 \%$ of the landed fish by value is subject to this system. The objective of the management system is to minimize the cost of catching and processing and to maximize the value of the catch. Increased confidence in the scientific advice on state of the resource coupled with firm fisheries control seems to be affecting the fish processing industry in a very positive way. Companies have been restructuring and specializing their processing and marketing. Many private companies have been merging, opening up to new shareholders and being registered on the stock market. Catching is getting more even throughout the year and there are several indicators that quality of the fish is improving due to better handling. Introduction of sophisticated technologies has cut cost. Vision technology and computerized systems are increasingly being used for producing high value products and monitoring quality and yields. Many companies are making an effort in product development, in marketing unconventional species and producing foods from "fish waste". Sound scientific knowledge on the fish stocks coupled with firm management seems to be turning the industry mentality from hunting into mariculture. Given the right institutional and economic framework the fish processing industry will make quality products from all catches - including by-catches and "fish waste".
\end{abstract}

Keywords: fish products, fishing technology, human consumption, management.

\section{Introduction}

It is estimated that some 840 million people are chronically undernourished in the world today and millions are malnourished at some time in the year (FAO, 1997a). Capture fisheries have a unique position in the food supply of the world as they represent large-scale gathering of food from wild nature. These organisms are free living and select their own food in the natural habitat and are therefore the most natural source of animal protein available for mankind. From the food technological point of view, fish are also unique in the way that the species are so many and different and that slaughtering cannot be done in a controlled way. Each species has its characteristics and undergoes seasonal variations to a varying degree. Because of this diversity, processing can be extremely difficult to mechanize and to standardize the products.

Figure 1 shows the world fish production over the last ten years (FAO, 1996, 1997b, 1997c). In 1995 it reached a record figure of 112.9 million tons whereof 81.9 million tons were used for human consumption. Aquaculture production reached a record of 18.6 million tons. If the aquaculture production is 


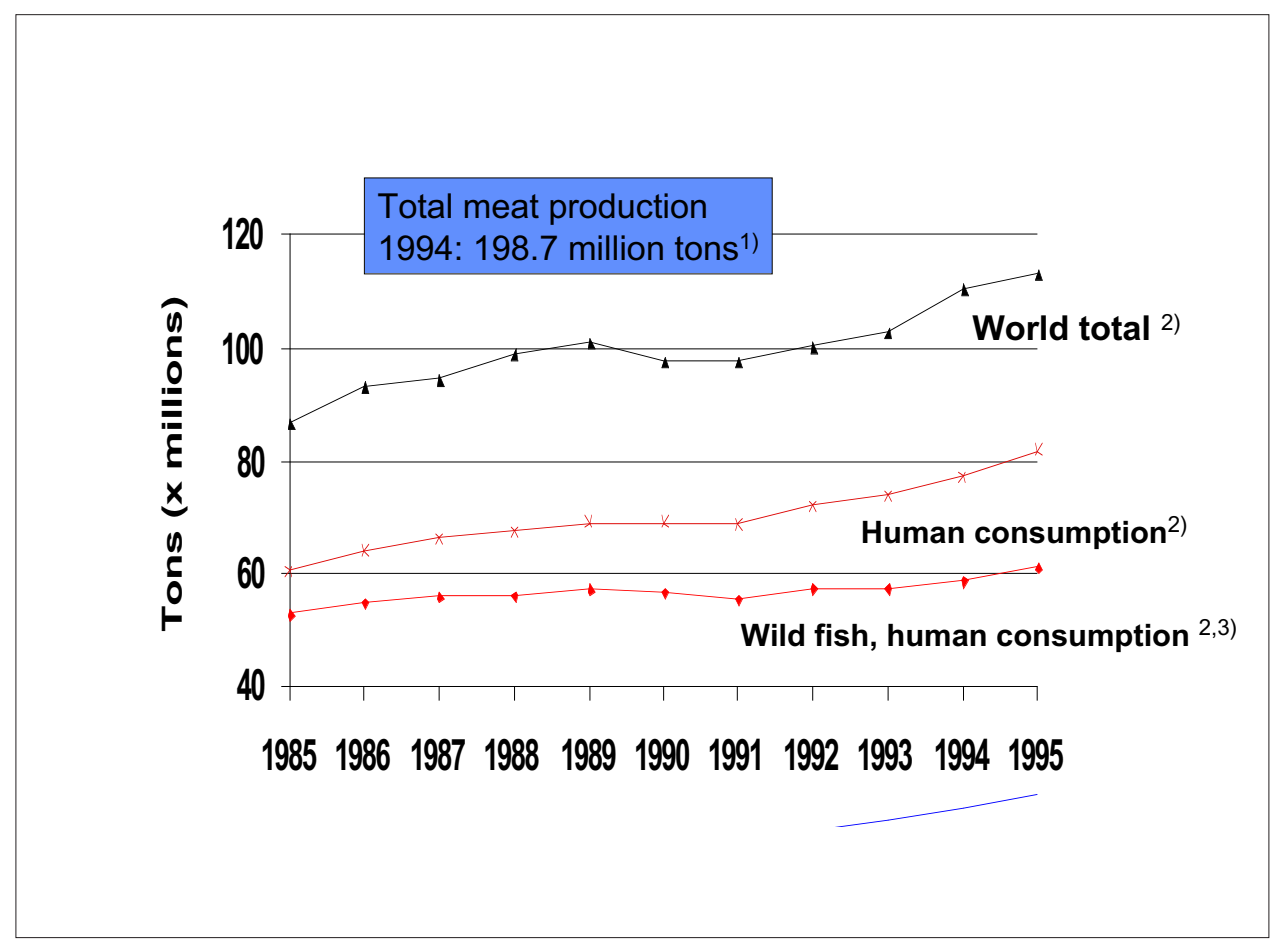

Fig. 1. World fish (and meat) supplies. 1) FAO, 1996; 2) FAO, 1997b; 3) FAO, 1997c. Wild fish for human consumption, 2-3.

subtracted from fish for human consumption we get a figure of 60 million tons for wild fish for human consumption in 1995. It is worth noting that of all fish for direct human consumption almost one forth comes from aquaculture. FAO estimates that under the present regime of exploitation the marine fisheries would be at full potential about now, i.e. at 82-83 million tons per year. With improved management of overfished stocks, and fisheries development in some parts of the world the total annual marine production could be at 110-125 million tons, but the authors stress that this perspective is highly uncertain (FAO, 1997d). The same report concludes that about $60 \%$ of 200 major fishery resources in the world are experiencing declining yields (senescent) or are mature. Until recently, aquaculture has been considered to hold promise for almost unlimited production. Now it is considered that due to lack of feeds and because of environmental constraints, aquaculture can only produce about 25 million tons by the year 2010 (FAO, 1995).

It has been documented that some 27 million tons or of fish are discarded at sea in course of fishing activities (Alverson et al., 1994). This represents almost one third of the ocean catch. In times of environmental concerns, marine fisheries in particular have come to the attention of the environmentally conscious public not to mention environmental activists. Questions are being asked about how we are exploiting the oceans and how present practices affect the earth's biosphere. There is general consensus that we have to conduct our fisheries in a sustainable manner. Sustainable development and responsible fisheries have become catchwords that we have live up to. The question, therefore is not if but how will this be done. How can we ensure that we exploit the marine ecosystem in a sustainable manner? How should we conduct our catching, management of the fisheries and processing in order to ensure maximum value with minimum costs?

In this presentation an attempt is made to present a scenario of recent developments relating to the fish industry in Iceland as these questions have a vital interest for the whole nation whose economy is highly dependent on marine fisheries for her livelihood. 


\section{The Icelandic Fisheries}

\section{General}

In Iceland the fish industry is by far the most important economic activity. It provides about $54 \%$ of the foreign currency earnings even though only $11 \%$ of the workforce are involved in fishing and fish processing. This national dependence on fisheries means that no state subsidies can be made to the fishing sector and in fact, a special levy is now placed on catch quotas to pay for fishing control, surveillance and the decommissioning of fishing vessels. Following decades of hyperinflation and state intervention the economic environment in the fishing sector is now market driven and profit oriented. This has led to significant restructuring of the industry as seen e.g. by the fact that private fishing and processing companies have been merging, operations restructured and increasingly they are opening up to new shareholders and being registered on the stock market. As a result demands for returns on investment in the fish industry is becoming more significant.

\section{Synopsis of the Icelandic fish industry}

Icelandic vessels catch around 1.5 million tons of fish per year, of which demersal fish is presently at around 500 thousand tons and about one million tons of capelin (Mallotus villosus) which is mostly used for fishmeal and oil. By value the most valuable demersal species is cod (Gadus morhua) giving over a quarter of the export value of fishery products followed by shrimp (Pandalus borealis). The fishing fleet is composed of 114 trawlers and some 700 smaller vessels. Most of the fish is processed in some 120 freezing plants around the country, 250 salt fish plants, 10 canneries and 20 fishmeal plants. Increasing amounts are being processed on board the freezer trawlers. The value of the catch in 1996 was 1.43 billion US \$. Figure 2 shows the catch from 1985 to 1996 (Fiskifelag Islands, 1994-96). Over this period severe constraints has been on the demersal fisheries leading to progressive restriction of catches. Catches of cod over the last six years have been cut down by $37 \%$ compared to the six preceding years. Demersal catches were cut by $17 \%$ over the same period.

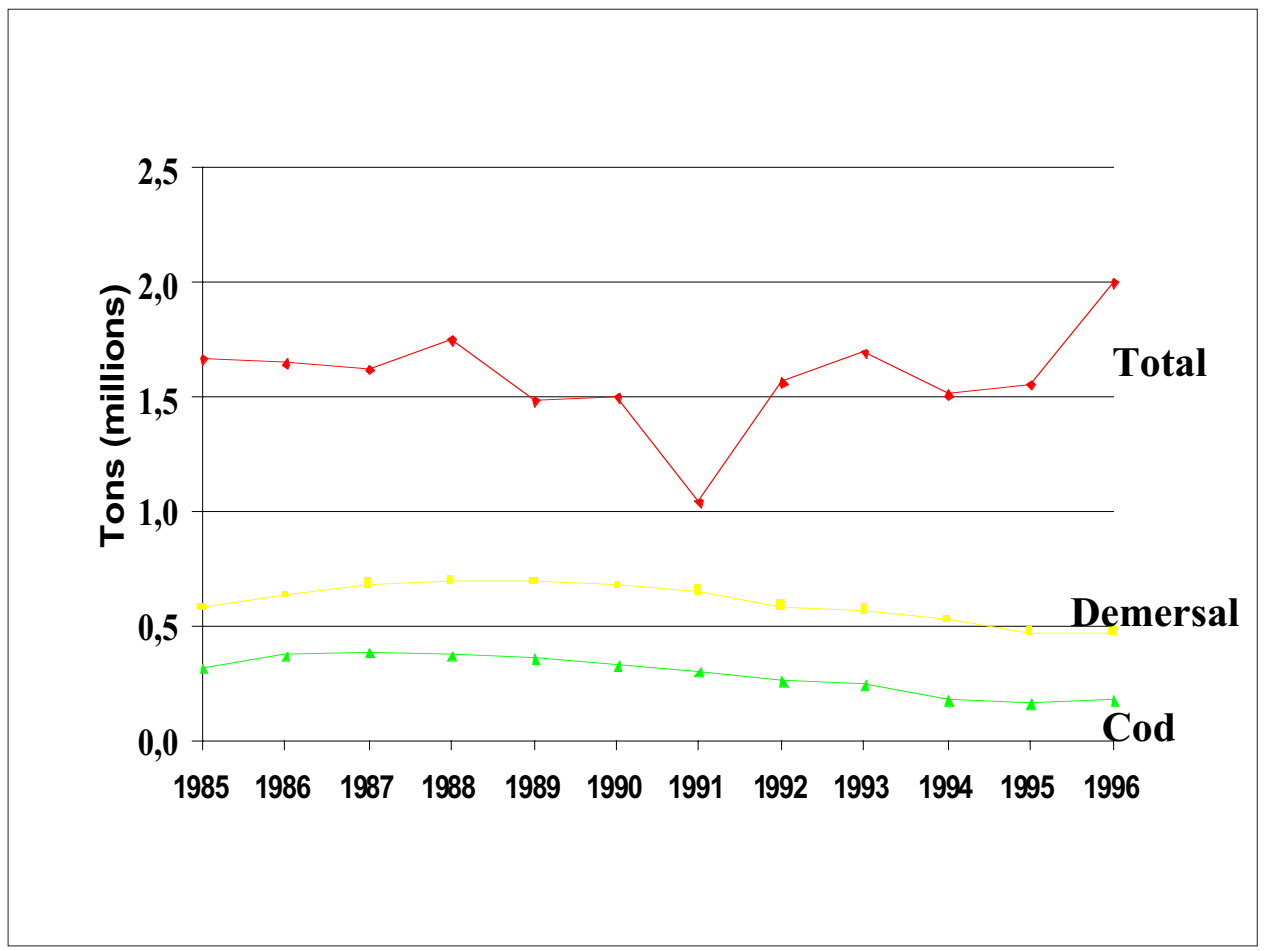

Fig. 2. The Icelandic catch, 1985-96 (Fiskfelag Islands, 1994-96). 


\section{The fisheries management system}

Iceland, as most other countries has been overfishing some of her stocks, but not to a crises level. In recent decades, Icelandic authorities been experimenting with various ways of regulating the fisheries to avoid overexploitation. The individual quota (IQ) system was introduced at different times in different fisheries, starting with the herring fishery in 1976 and the capelin fishery in 1980. In 1984 the Icelandic Parliament passed a legislation which made all the major stocks subject to individual quotas linked to each vessel and in 1990 a complete uniform system of transferable vessel quotas (ITQs) in all fisheries were in place. In 1991 the effort quota option was eliminated. Also, a major change was that it became legal to transfer permanent quota shares between vessels. Presently, over $90 \%$ of fish by value are landed under the ITQ management system and it covers all vessels over 6 GRT. In 1995 the government adopted a new approach for setting the TAC for cod i.e. to take $25 \%$ of the average of the estimated fishable stock (Danielsson, 1997). The objective of this formula is to persuade the politicians to follow a consistent policy of utilizing the cod stock. These changes have been affecting the industry greatly, both the fishing and the processing. In an attempt to estimate the economic efficiency of the Icelandic fisheries as a result of the ITQ system, Arnason came to the conclusion that significant rents are being generated by the system (Arnason, 1990).

In his analysis of productivity in the Icelandic fisheries, Danielsson (1997) found that productivity of labour and capital in the Icelandic fishing sector was very significantly higher in 1992 than in 1973. This increase was mainly attributed to the size of the fish stocks but definitely not between the years of 1984 and 1988. His conclusion was that development of technology including the freezer-trawler technology explains this improvement in productivity but mostly changes in the fishery management system (Danielsson, 1994, 1997).

In a small society so dependent on fisheries the debate on all aspects of business is very lively. There is by no means general consensus that the ITQ system is the best. There is, however, a general consensus that the fisheries have to be strictly controlled. Also, there is growing confidence in the quality of the scientific advice given by the Marine Research Institute. In recent years the Minister of Fisheries has been determining the annual quota allocations ever closer to the scientific advice. However, voices about free access to the fishing grounds have silenced.

The system of fixed transferable share in the fishing stocks has caused a major change of attitude towards the fisheries industry. No longer there is a race in the fishing as is the case with effort quotas, and the days are gone when quotas could be increased by political pressures. This has caused a genuine incentive to make the most value out of the fish available with minimal cost. This has occurred in the whole chain of operations, from the fishing grounds to the consumer markets.

The IQ system obviously puts pressure on the fleet to utilize unconventional species, which are not covered by the quota system. The main effort in this respect has been outside the Icelandic Exclusive Economic Zone, mainly for deep-sea rosebush on the Reykjanes Ridge. To encourage such utilization of unconventional species the Icelandic Fisheries Laboratories operated a so-called By-Catch Bank from 1990 to 1994. Its activities were mainly focused on the freezer trawler fleet, i.e. to encourage these vessels to bring ashore the unconventional species. The Bank guaranteed a minimum prize for the fish and then acted as a matchmaker between the fish owners and marketing firms for selling the fish. Some species have entered commercial exploitation through this project (Thorsteinsson and Valdimarsson, 1995). Table 1 shows the development of the catch of some unconventional species in Iceland from 1989 to 1996 (Fiskifelag Islands, 1994-96). 
TABLE 1. Catches of some unconventional species.

\begin{tabular}{lrrr}
\hline \hline & \multicolumn{3}{c}{ Tons } \\
\cline { 2 - 4 } Species & 1989 & 1992 & 1996 \\
\hline Grenadiers & 2 & 210 & 808 \\
Starry ray & 99 & 317 & 1493 \\
Greater silver smelt & 8 & 657 & 808 \\
Deep-sea rosefish & 1374 & 13845 & 52994 \\
American plaice & 565 & 1468 & 7027 \\
Dab & 2233 & 3044 & 7954 \\
\hline
\end{tabular}

Source: Fisheries Association of Iceland, 1994-96.

\section{Fisheries control}

It is well known that with an ITQ system it is necessary to have very good records of all quotas and quota transfers. Also, accurate weighing of all catches must be done at the 125 authorized weighing centres around the country. Detailed reports of species and weights are fed to a central computer system and are monitored on a daily basis by the authorities. Also, the quota situation for each vessel can be followed on the Internet, i.e. how much remains to be caught during the quota year. One of the problems with an individual quota system is discards as the fisheries must be conducted in such a way that the they not only have a quota for the target species, but also the by-catches. At first this was a problem causing complaints by the fishermen, but now it seems that by making it the responsibility of the fishermen to have the right species balance in the quota composition the system seems to be working quite well. Having an open quota market also makes it possible for a vessel exceeding its quota for a given species to buy an extra quota. Such transactions are often made through the ship radio before entering the port. Public outcries of alleged vast discard problems led to an independent study to evaluate the extent of the problem. It was estimated the discard rates were within $6 \%$ of the total catch (Anon., 1993). Much discussion on the problem has undoubtedly increased public awareness of the problem, not the least among fishermen.

One aspect of the fisheries control in the IQ system is regarding vessels processing at sea, bringing only fillets ashore. There has been a very significant development in processing at sea, especially in freezing, filleting at sea and even salting. Figure 3 shows this development (Fiskifelag Islands, from database, 1997). From 1985 there has been a constant increase in processing at sea especially freezing of fillets amounting to 194.9 thousand tons (wet weight) in 1996. The value of the sea frozen products amounted to $22.4 \%$ of the value of all exported fishery products. Many factors have contributed to this development, better processing equipment, marine scales allowing accurate weighing at sea and not the least higher price for sea frozen products. For cod processed at sea, over $47 \%$ of the products are skinless and boneless fillets. With the IQ system yields for the processing vessels have had to be dealt with as the quota used by them has to be determined by the amount of landed products. To monitor the quota, the filleting yields have to be determined for each vessel as they differ considerably from one vessel to another. Fish inspectors do their own measurements when inspecting on board the vessels and crews are obliged to take regular samples, fill in precise records regarding the yields and send copies to the Directorate of Fisheries. Attempts are being made to assess the filleting yields by inspecting the landed products, but it is evident that as more consumer cuts will be made on board this will be very difficult (Birgisson and Eyjolfdottir, 1997). 


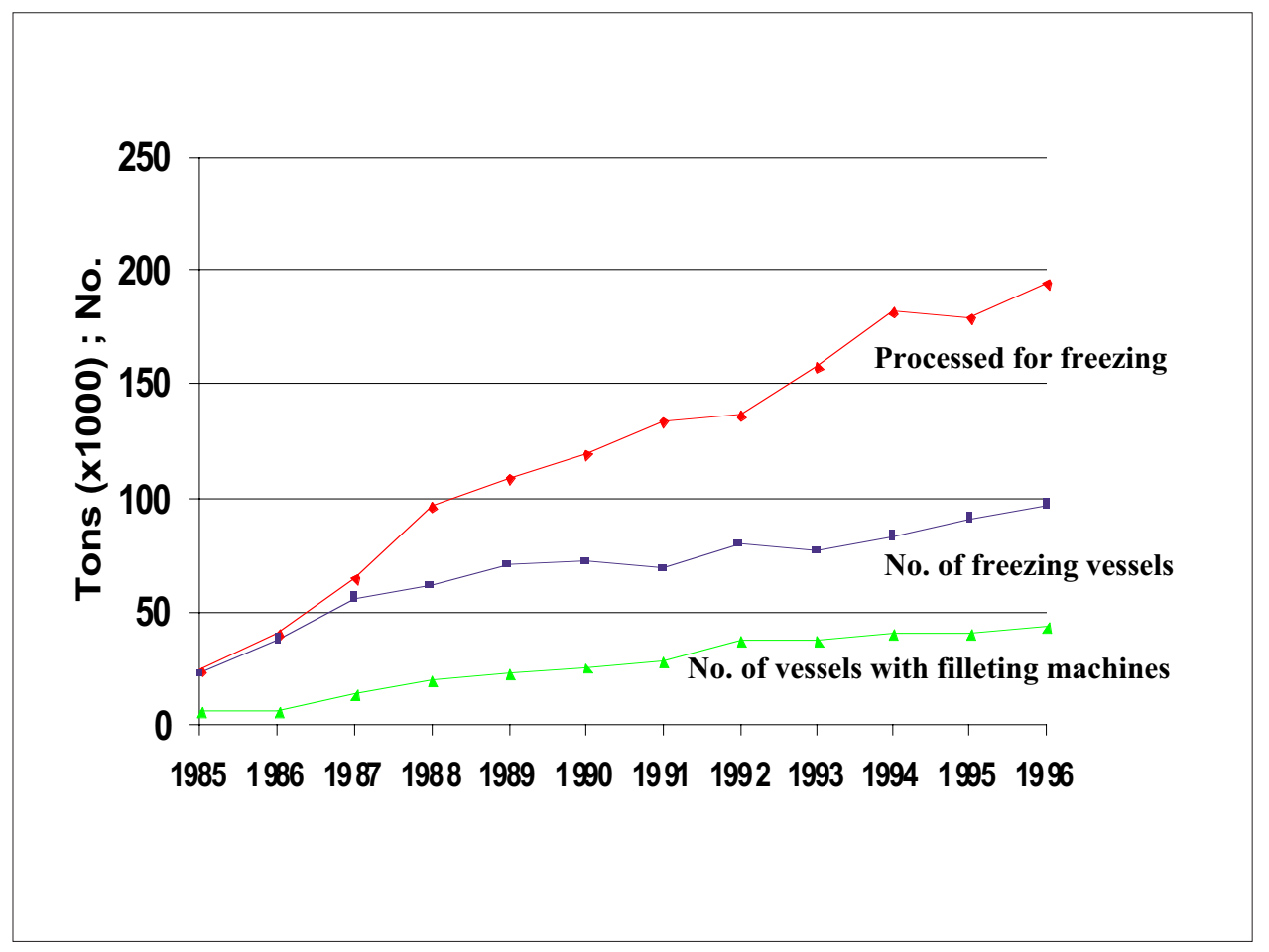

Fig. 3. Freezing and processing at sea (Fiskifelag Islands, from database, 1997).

\section{Fish markets and quality of raw material}

It was in 1987 that the first Icelandic auction floor market opened. Prior to that time the minimum fish prices were negotiated between fishermen and vessel owners. The argument against the markets was that in the rural communities a market could not be operated. One of the fish markets established a computerized system early on for auctioning fish. A new system was established in 1992 with the result that the computerized market serves today 19 harbours around the country. As seen from Fig. 4, the quantity of fish auctioned in the rural areas in Iceland has steadily increased with the computerized markets (Johannesson, Sudurnesja Fishmarket, pers. comm., 1997). Fishing vessels can give detailed information on the fish they have caught, such as species, size, day of catch, etc. A computer centre electronically connects the auctions in various locations around the country. Connecting to these is very inexpensive. The auctions invoice all buyers, disburse sellers and forward payments and fees to port and government authorities (Gudjonsson, 1997). Iceland is participating in a European project, Informar, which will make it possible to electronically trade fish throughout Europe. The project, which will be finished in 1998, will make it possible to trade fish while on board the fishing vessels using Inmarsat-C or mobile phones (Holmes, 1997). There is general agreement among fish processors that the electronic fish markets have revolutionized the access of companies to fresh fish. They have made specialisation in processing much more common. Even though there appeared to be quality problems with the auctioned fish in the first years, it seems that as confidence has grown in the system, fish is increasingly being size graded and labelled with regard to date of catch. Even though the fresh fish market has been a "seller's market", in recent years there is consent that fresh fish quality has never before been so well reflected in the price and that graded and properly labelled fish is beginning to fetch higher prices. The electronic markets provide an excellent opportunity to study the price structure and what features in the handling mostly affect the price structure. Figure 5 shows the different price for iced cod at one market over a whole year (Rikhardsson et al., 1996). Information on the market prices is available for the fish processors to study, effect of season, sizes, methods of catching, gutting, icing, etc. 


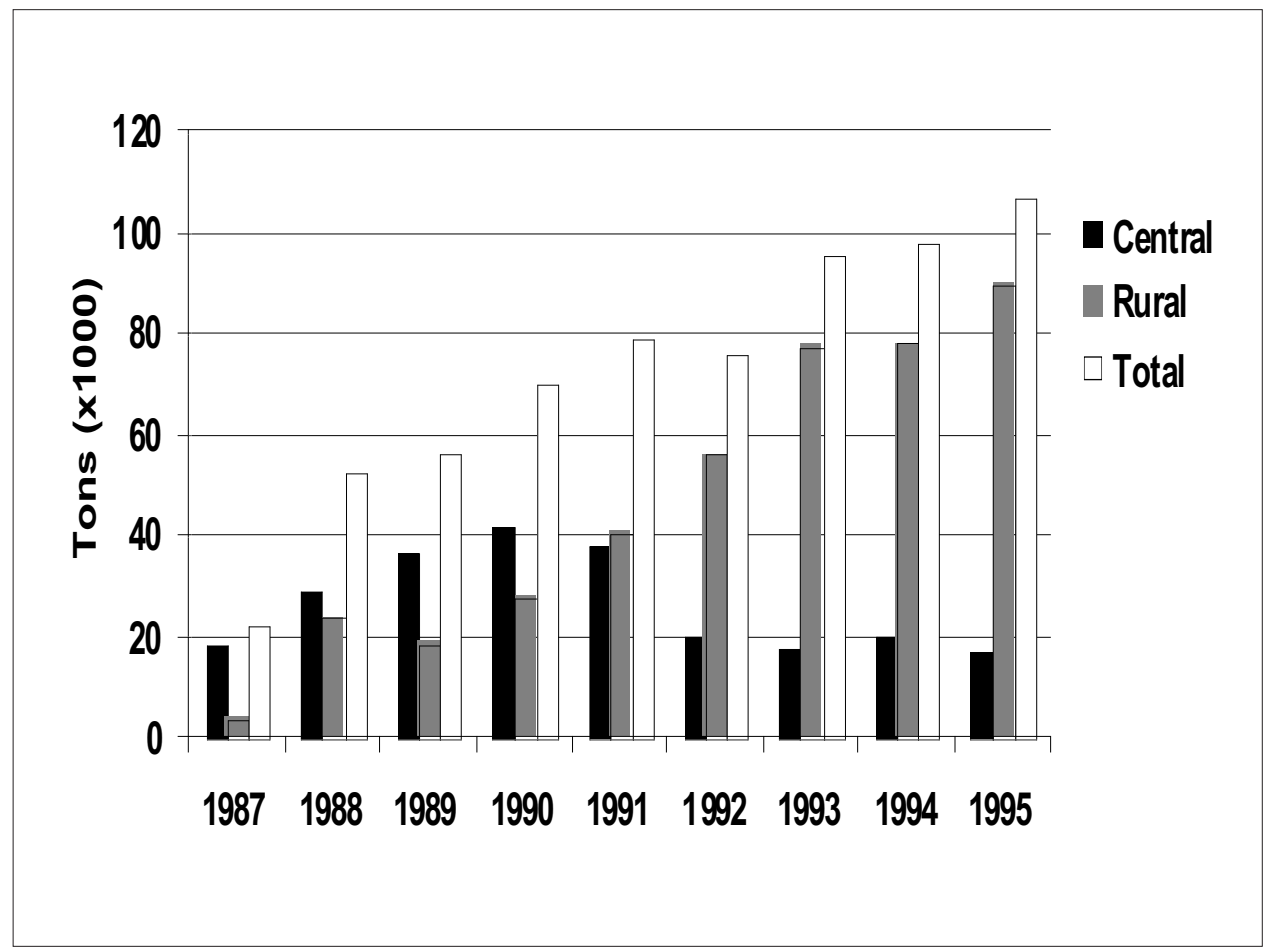

Fig. 4. Development of fish telemarkets in Iceland, 1987-95 (Johannsson, 1997, pers. comm.).

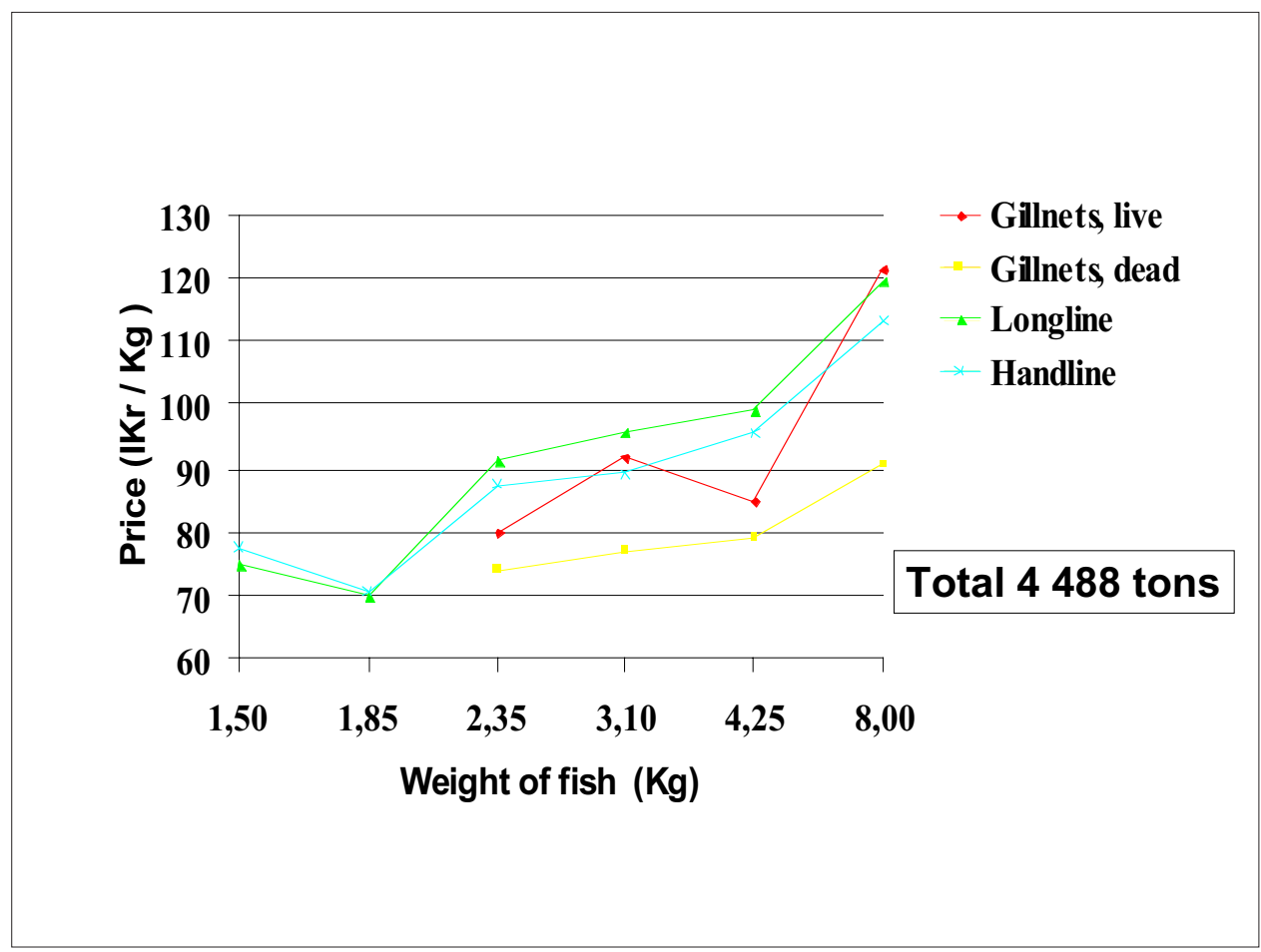

Fig. 5. Price of whole cod on the FS market in Iceland, 1995 (Rikhardsson et al., 1996). 
There is evidence to show that the management system used for the fishing significantly affects the quality of the landed catch. Sigurgeirsson (1995) analysed landing patterns for Icelandic cod from 1977 to 1993. Some of the results, shown in Fig. 6, demonstrate that variability in landings was significantly different for the two periods corresponding to restricted effort and IQ management regimes. The data shows for example that in 1981 some $49 \%$ of the annual catch of cod was landed in a period of three months, i.e. in March, April and May. In 1993 the corresponding figure was 28\%. It also seems that the value of cod products per ton of caught cod did increase with implementation of the IQ system even though the author is cautious about the interpretation of this data (Sigurgeirsson, 1995). Another study by attempted to compare the market share of cod fillets on the United Kingdom market (Fig. 7), indicating that the fish industry was increasing the value of cod fillets on this market but with a smaller share of the quantity (Gretarsson, 1994).

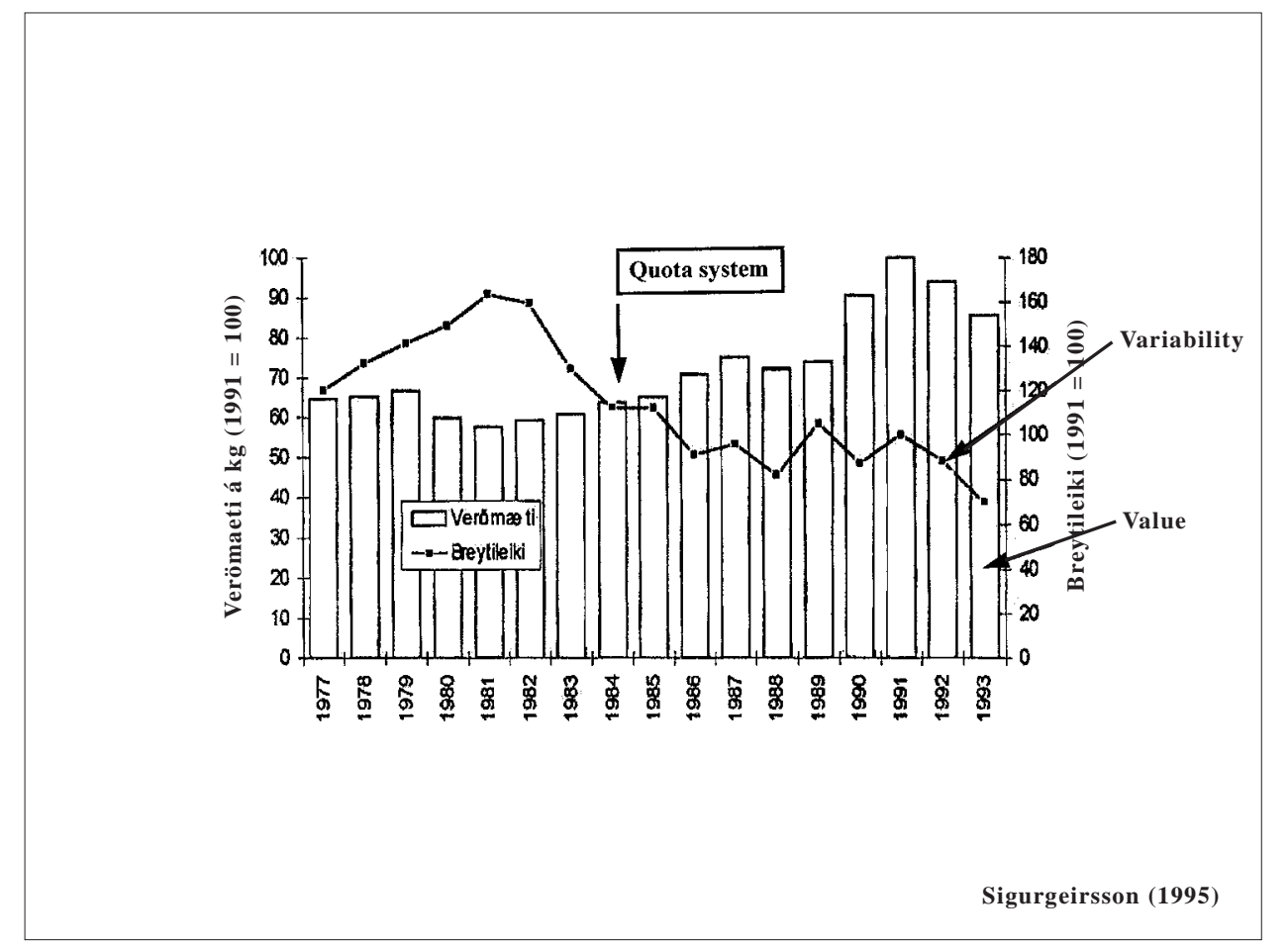

Fig. 6. Variability of landed cod and value per unit of catch (Sigurgeirsson, 1995).

\section{Developments in Fish Processing Technology}

Valdimarsson (1992) presented an overview of technological changes in the Icelandic fishing industry since 1965 in an attempt to identify causes and effects. In recent years the fish processing industry in Iceland has undergone major changes and is adopting new technologies and production systems. There is no doubt that the ITQ system has put significant pressure on the fisheries to economize and use technology as much as possible to cut down costs and increase value. As seen in Fig. 8 the export of unprocessed fish to continental Europe has sharply dropped (Anon., 1997), whereas exports of fresh fillets by aeroplanes have gone up (Fiskifelag Islands, from database). Attempts to increase value of the products are also reflected with an increase production of capelin (Mallotus villosus) for human consumption as seen in Fig. 9. The number of fishermen and processors has gone down by some $10 \%$ from 1985 (Fig. 10). It seems that investment in new processing equipment plays a significant role in that respect. 


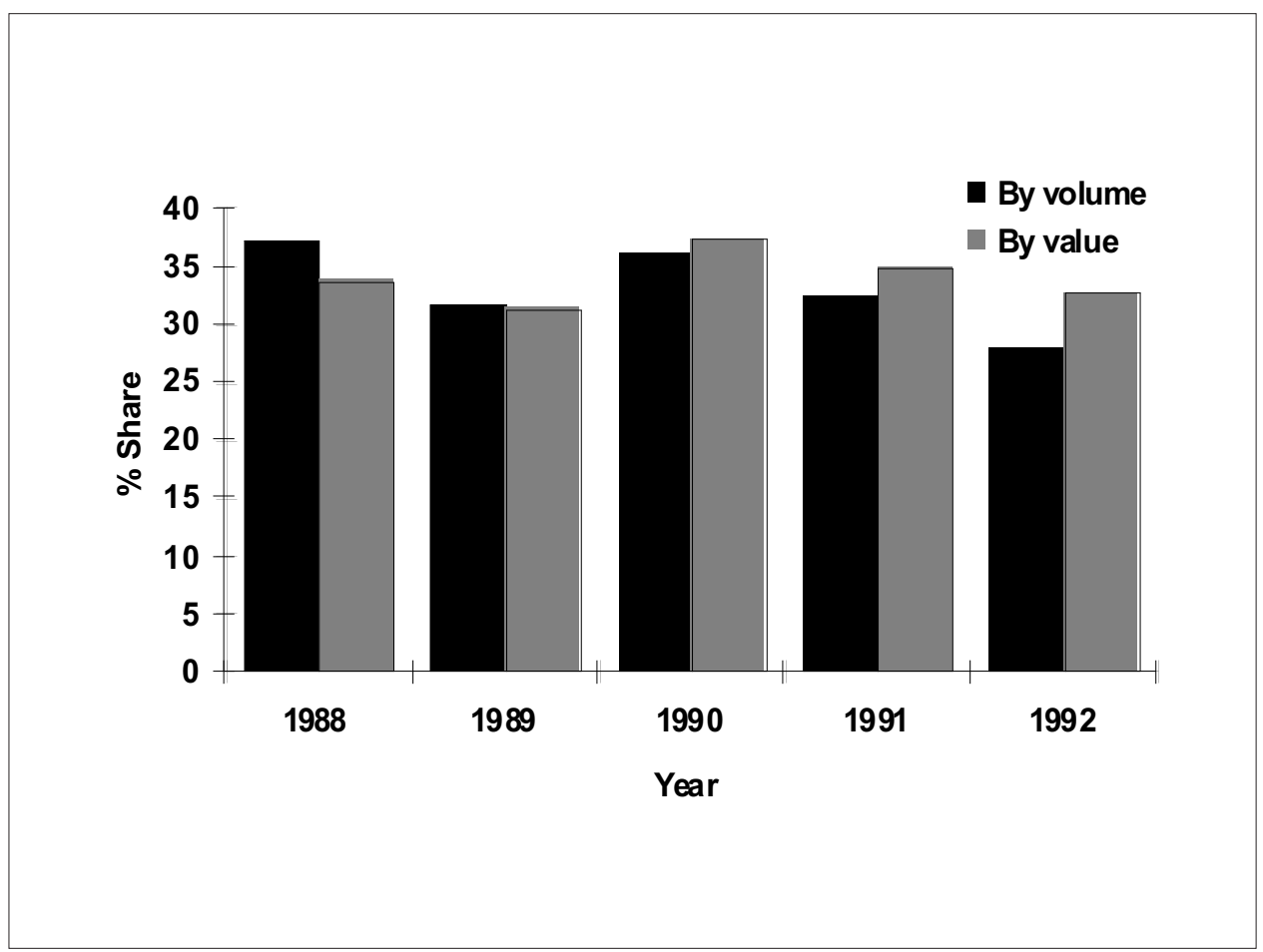

Fig. 7. Market share of Icelandic cod products on the UK market (Gretarsson, 1994).

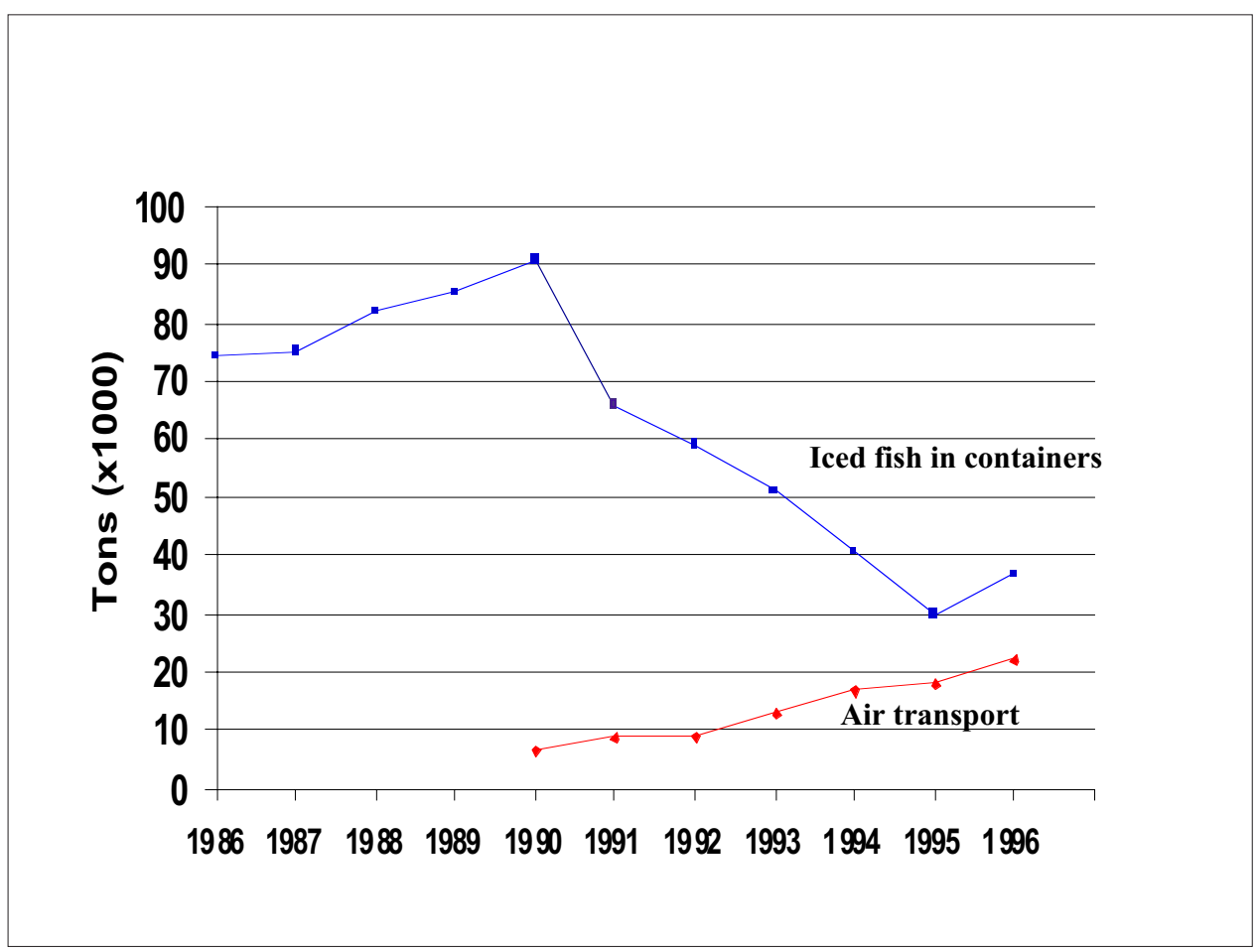

Fig. 8. Export pattern of fresh fish (Anon., 1997; Fiskifelag Islands, from database). 


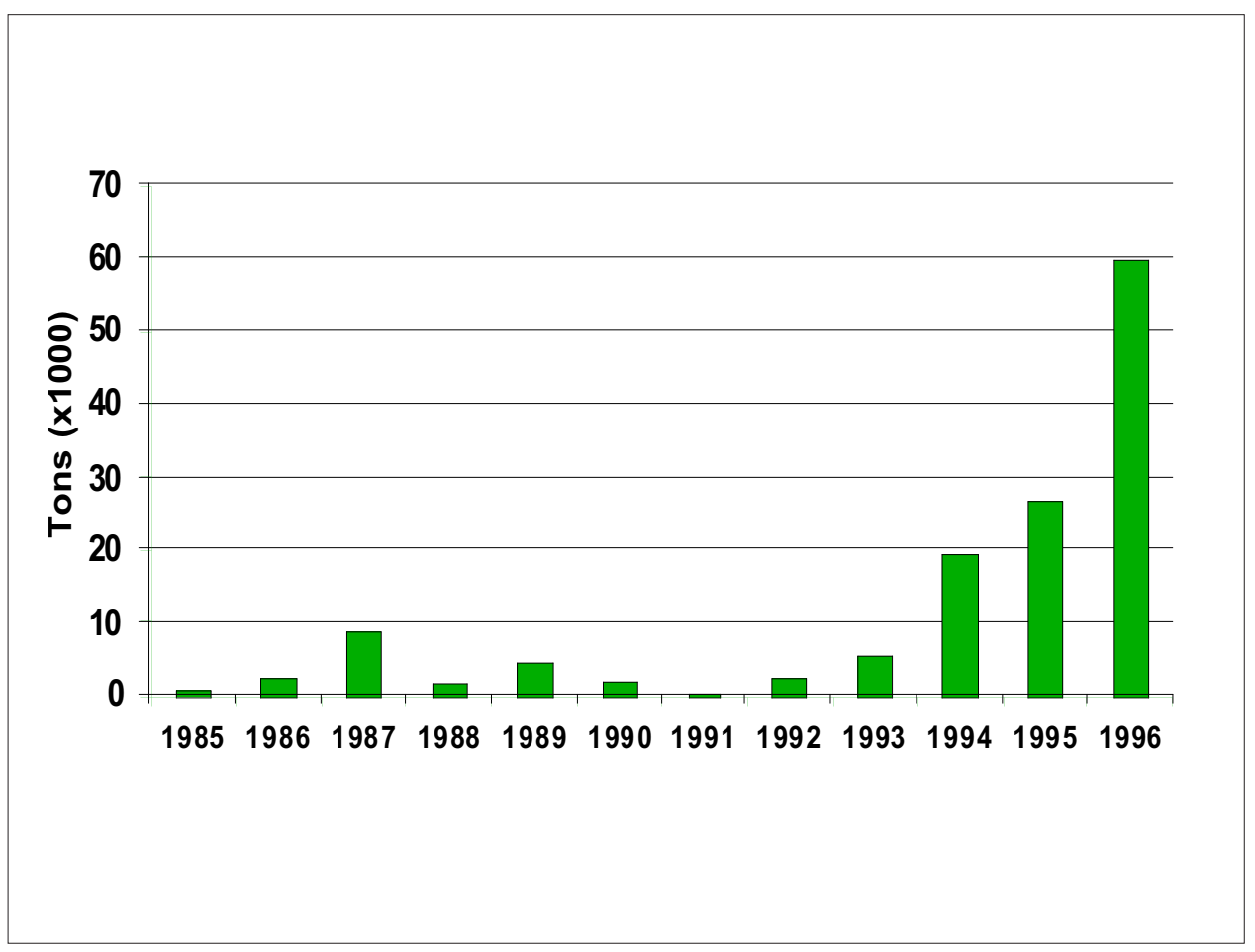

Fig. 9. Production of capelin for human consumption (Fiskifelag Islands, 1994-96).

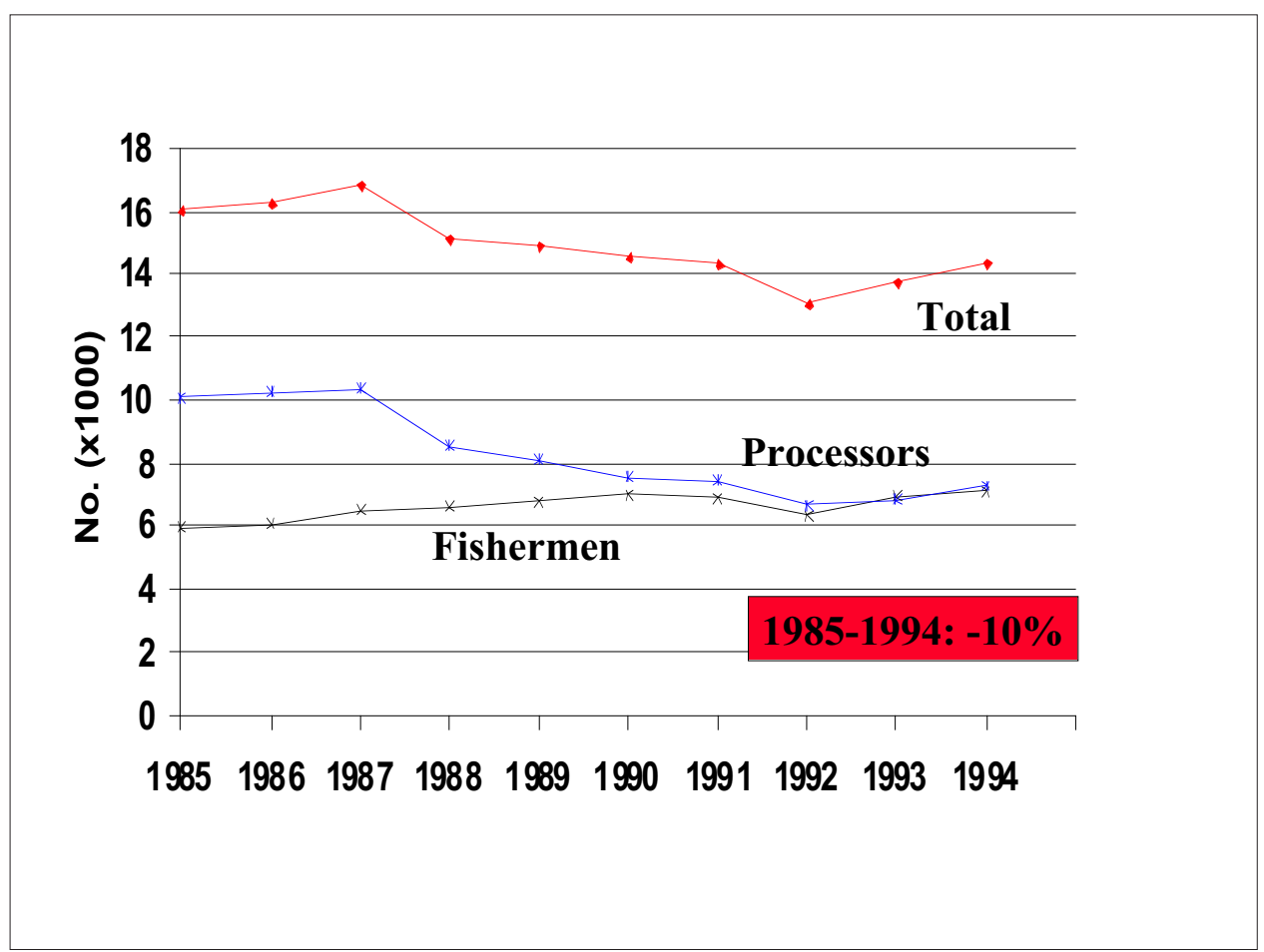

Fig. 10. Number of fishermen and fish processors (Fiskifelag Islands, 1994-96). 
Electronic scales and vision technology. The incentive to use electronic scales in Icelandic freezing plants materialized in 1977-78 when fish stocks were dwindling and production costs were rising. There was a need to improve yields by monitoring inputs and outputs as well a possible. This need was also evidenced by the fact that most of the plants used at that time complicated individual incentive schemes that required detailed data, which were used for calculating the workers' pay. Gradually, most plants were using information systems, making it possible for monitoring at all key locations of the processing lines as well as quantities of fish to and from individual workers. By linking the weighing systems to computers, it has become possible to keep a record of yields at all the major steps in the production. Various variants of this technology have now come in general use, such as continuous flow scales and scales that select the best combination of pieces for a given pack. The electronic scales have laid the basis for today's information systems within the freezing plants. By giving production managers easy access to key information on yields and performance, these systems have provided the necessary tools for applying modern production managing techniques. It can be said that all the larger fish processing plants in Iceland are now using complete systems for keeping track of all such data. Development of the marine scale was major step in processing at sea. All of the Icelandic processing vessels now use these systems on board their vessels. This equipment has become a major export item for the two Icelandic companies making them, Marel Ltd and Pols Ltd. Some vessels are using best combination sorters on board, some have started to produce consumer packs for shrimp based on this technology and vision-portioning lines are being installed.

Even though vision technology has been used to some extent in fish processing for a number of years, it seems that it is now beginning to find wide application. Basically, a three dimensional picture is taken of the fish, the picture is then analysed in a computer. The digitalized data can then be used for various purposes, such as measuring length, for sorting and calculating volume (and thus the mass) (Arnason and Khodabanehloo, 1993; Shaw, 1993). Today, vision technology is mostly used for portioning fillets to accurately weighed pieces conforming to certain dimensions. In Iceland some 15 such units are in use in the fish industry. Automatic sorting according to shape is also becoming common as some ten such units are already in use in Iceland. High speed sorting of fillets according to colour is also starting and the same is true of quality grading salted fish. Quality grading of herring fillets, looking for blood spots, etc. can be done at speeds of 500 fillets per minute (Gunnlaugsson, 1997).

Production lines in filleting plants. The most work demanding operation in a filleting plant is the trimming and packaging of fillets. Around 1970 most plants started using plastic trays for transporting the fillets from one processing stage to another, using a conveyor belt. This batch type procedure made it easy to monitor yields and it laid the basis for an individual pay incentive system. This system, however, became very complex, as it not only took into account the volume each worker produced per unit time but also the quality and yield of the final product. In 1988 a major modification was introduced when the first so-called "Flow Line" was installed. Now most of the freezing plants in Iceland have installed Flow Lines. Fillets are not put in trays, but moved along individually on conveyor belts. This meant changing the individual bonus system to a collective wage incentive system. The main advantage of this arrangement is reduction in manpower, ergonomically better working conditions resulting, increased efficiency of workers and better packaging yield of fillets. The average time from filleting to packaging is commonly only 5-7 minutes with this system (Arnarson, 1991). The disadvantage of this system, however, was that an important quality parameter was lost i.e. the possibility of being able to link each pack of fish to an individual worker. Therefore, a new generation of flow lines has emerged, the Individualized Flow Line (IFL). The first line was installed in 1992, but now some 50 plants have installed them worldwide. This type of processing line will be described here, as it seems to be the precursor to the fully automated trimming, cutting and packaging line. The operation in the IFL is composed of three stations. The skinned fillets enter on a conveyor belt to the first station, the trimming station. Each worker at the trimming station sorts the fillets or fillet pieces into product bins at his station after making the necessary cuts. For this purpose there are four options. When cod fillets of mixed quality are being processed they can select the following four groups: (1) Fillets for making special cuts (2) small or torn fillets for a block (3) bellyflaps for block and (4) small pieces and pin bone cuts for mince. The product bins are automatically emptied onto a single conveyor belt directing the product on a flow scale for registration of source, 
type, quantity and direction. The conveyor belt takes the products to the next station, e.g. fillets for making special cuts. Each portion is automatically brought to the right slot at the cutting station and finally to packaging. The system automatically records all the parameters for yields for each worker. Moreover, the computer automatically selects a sample on random basis for quality inspection, the results of which are also logged into the computer. The main advantages of this system is that the information on yields and quality parameters are linked to individual workers which has given significantly better results than for the conventional Flow Line. An example on the information available from the system is shown in Table 2. The concept of the "intelligent factory" is clearly beginning to materialize (Gunnlaugsson, 1997). The kind of information used in the portioning process is shown in Fig. 11, i.e. how portioning is dependent on fillet size and how that affects the price (Icelandic Freezing Plants Corporation, 1997; from company pamphlet). Portioning is evidently a good business as production of fillet portions has been growing significantly in recent years as seen in Fig. 12 (Icelandic Freezing Plants Corporation, 1997; Iceland Seafood Ltd., 1997; adopted from company pamphlets). One aspect of the information technology coupled with the new generation of processing lines is constant monitoring of the value of products that can be processed from a given raw material as seen in Fig. 13 (Rikhardsson and Birgisson, 1995). Also, traceability from fishing ground to the consumer is not only useful for e.g. quality control purposes, but could also eventually be used for answering question by the consumer in the supermarket or the restaurant. Information could be approached about where the fish came from, where and when it was caught, where processed and so on (Bjartmarz, 1997). Such information could be done via the Internet and satisfy the most stringent requirements for traceability (Fig. 14).

TABLE 2. Data from an individualized Flow Line on fish processing efficiency.

\begin{tabular}{ccccc}
\hline Worker & Amount $(\mathrm{kg})$ & Defects & Yield (\%) & Efficiency $(\mathrm{kg} / \mathrm{h})$ \\
\hline 1 & 63.8 & 0.0 & 93.3 & 22.1 \\
2 & 189.2 & 0.6 & 92.8 & 65.7 \\
3 & 128.4 & 1.8 & 88.8 & 36.9 \\
4 & 47.8 & 2.0 & 87.2 & 75.9 \\
\hline
\end{tabular}

Courtesy of Marel Ltd.

By-products and fish waste. The fish industry has been termed a by-products industry because less than half of the whole fish is utilized for the main products. The rest is either discarded or processed into fishmeal and fishoil. Significant effort has been made in Iceland for improving the use of fish waste and with some results. For the years 1982-85 it was estimated that out of a demersal catch, including shrimp, of almost 600 thousand tons, 288.5 thousand tons were available as raw material for by-products. It was estimated that 212 thousand tons were utilized, thereof 20.2 thousand tons for human consumption but the rest for fishmeal and oil (Valdimarsson, 1990). A later study showed that whereas more was being processed for human consumption, mainly fish heads, more was being discarded due to increased processing at sea (Arnason et al., 1994). Traditional by-products include fish liver; tongues and cheeks cut from fish heads and mince from fish frames. In recent years significant development has been taking place in better utilisation of fish heads. Machinery has been developed for cutting tongues and cheeks from fish heads and markets have been found for increased amount of this product. The main use of fish heads, however, has been drying for the African market. Export figures for head products are shown in Fig. 15. At present there is considerable development in utilizing by products. Examples include salting of collars and offcuts from roundfish processing followed by deboning which has resulted in a new product which can be used for ready to eat "baccalau" type products. Whereas the mechanical problems for various processes seem to have been solved satisfactorily, product development and marketing of the by-products could be improved. A new technique of high pressure spraying of fish frames for removing the remaining fish flesh has resulted in washed fish mince, which has potential use for various products. The utilisation of by-products 


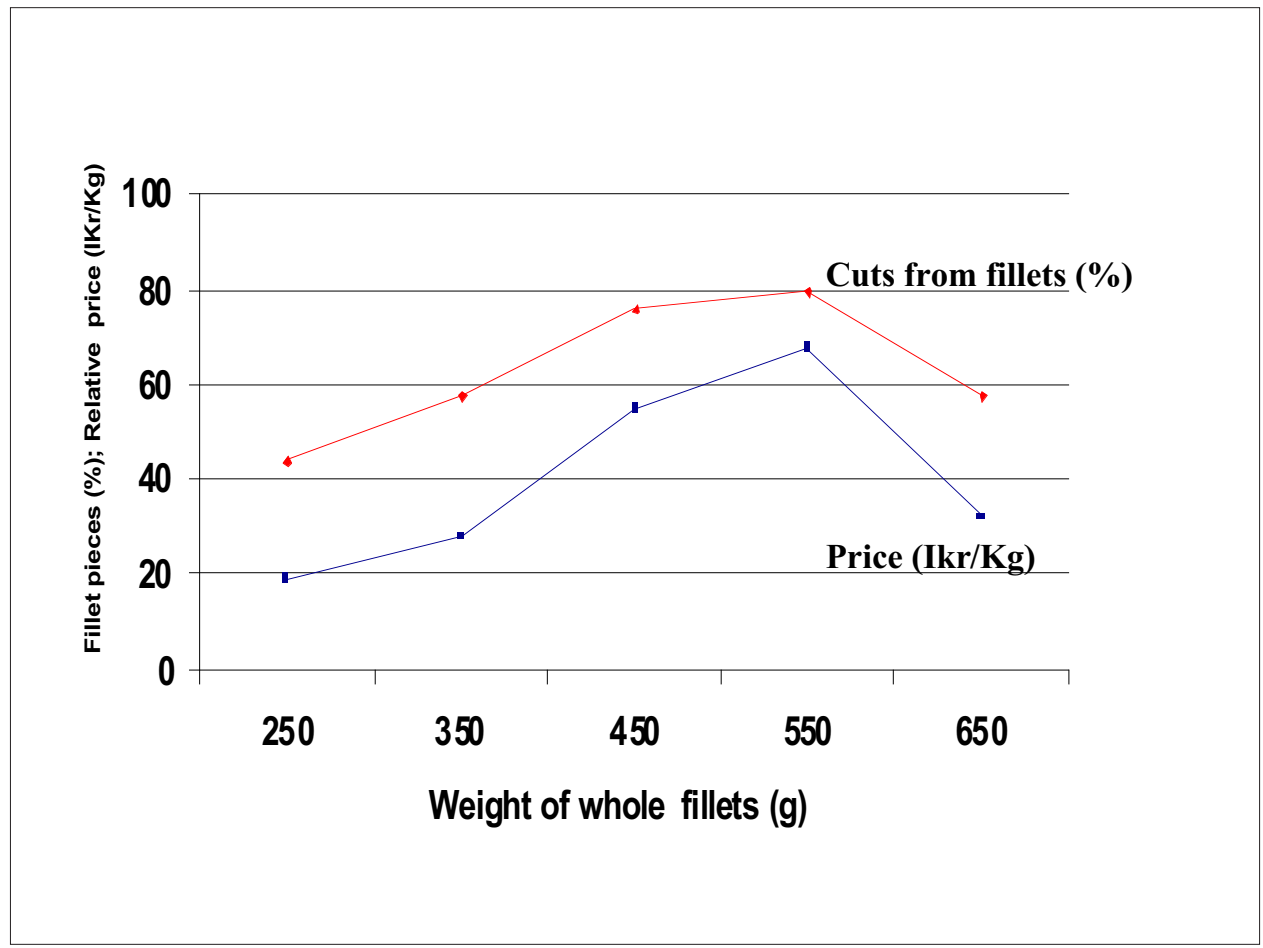

Fig. 11. Portioning of cod fillets (Pamphlet from the Icelandic Freezing Plants Corporation, 1997).

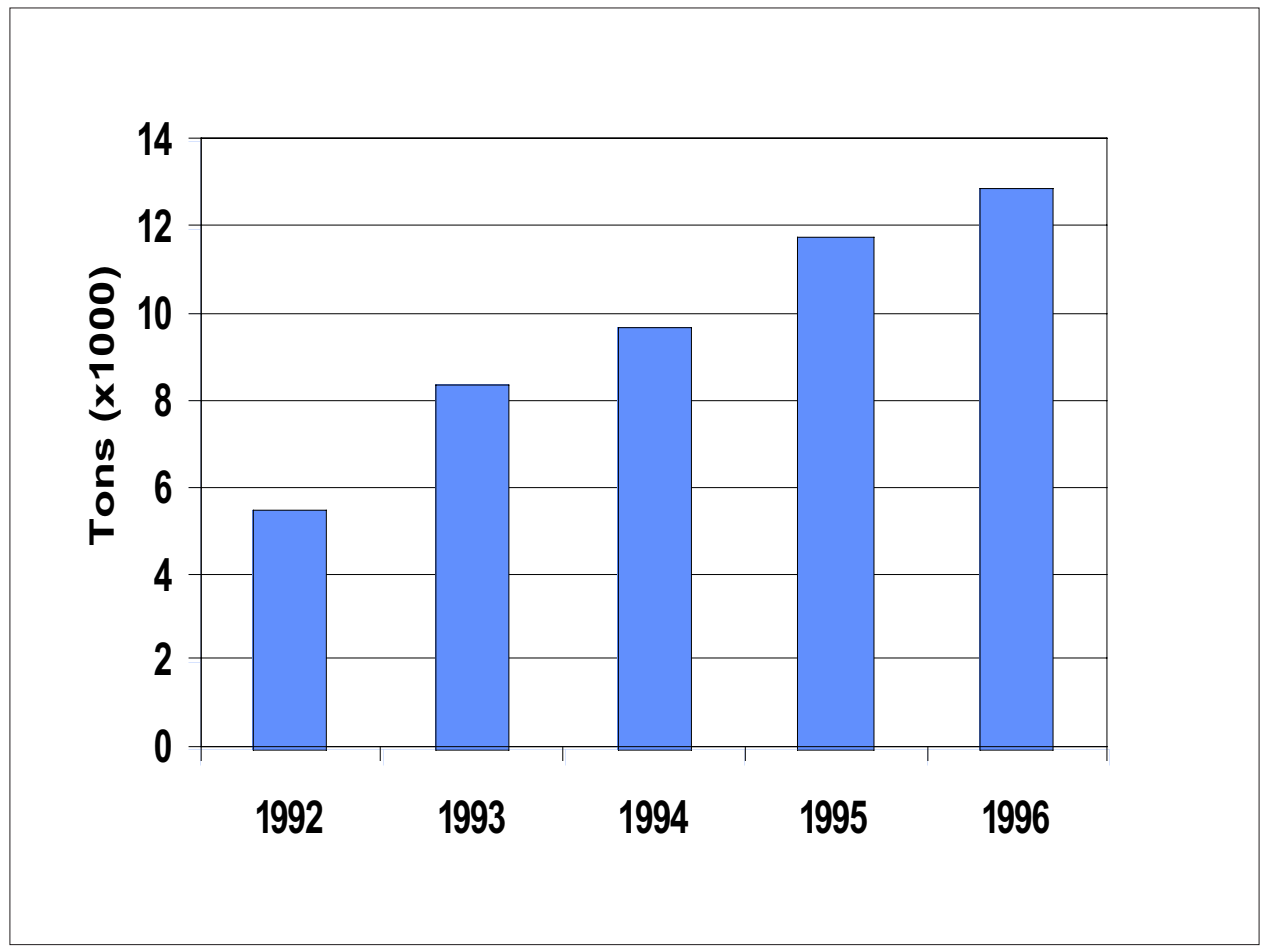

Fig. 12. Production of value added products made from cod fillets (Pamphlets from the Icelandic Freezing Plants Corporation and Iceland Seafood Ltd., 1997). 


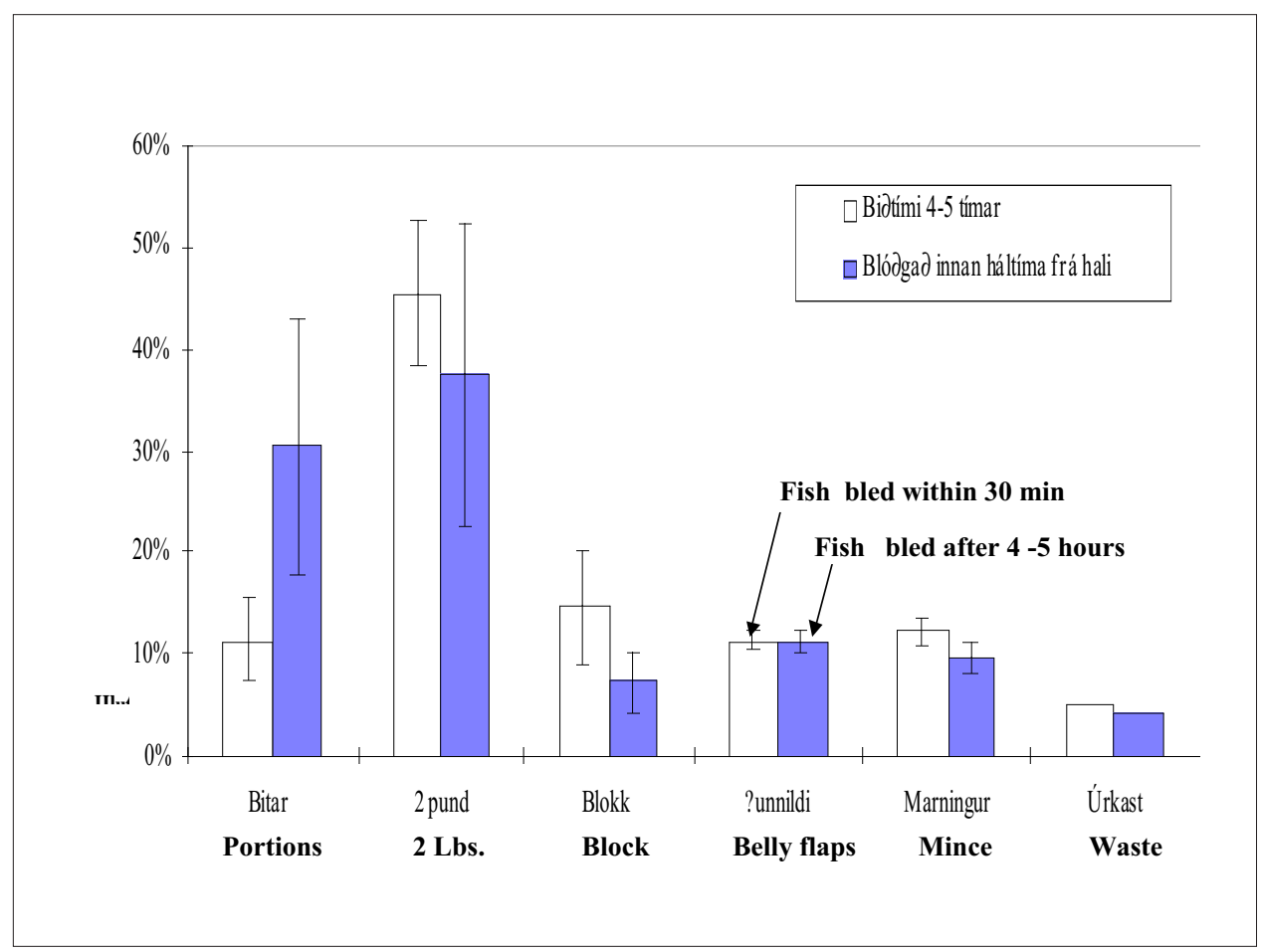

Fig. 13. Products from cod of different quality (Rikhardsson and Birgisson, 1995).

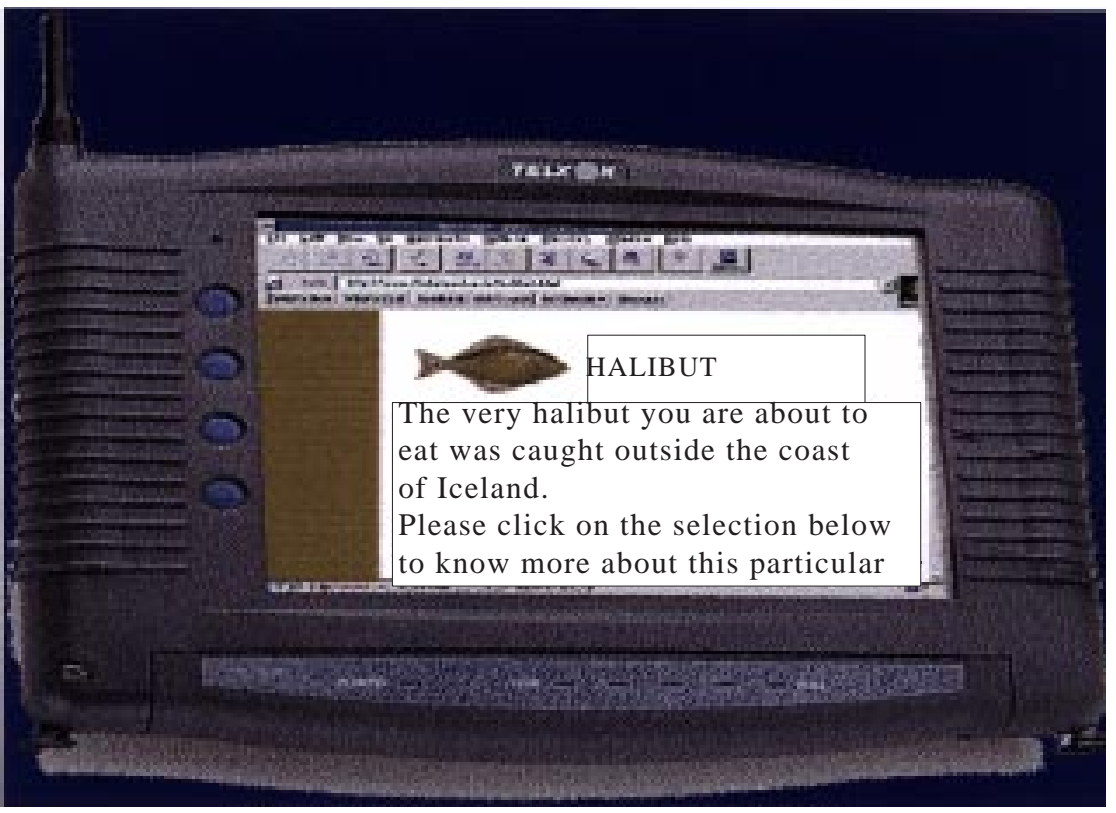

Fig. 14. On-line information: traceability (by courtesy of Taeknival Ltd.). 
is in most cases a question of processing low value raw material economically. Experience seems to indicate that e.g. processing all by-products from a cod salting operation can give some $10 \%$ of the value of the main products and in operational terms is at present only marginally profitable (Asbjornsson, Fiskkaup Ltd., per. comm., 1997). Thus, fish waste should be looked at as a potential raw material for various products. It is a challenge for the fish industry to find economical ways of utilizing this raw material. A study was made on technological possibility and the economic benefits of bringing ashore all of the discards from the Icelandic freezer trawler fleet. Various scenarios were evaluated, including fishmeal production, silaging, freezing of split fish heads and mince production. The main findings of this study were that fishmeal production is not profitable at all. Investments with the sole purpose of utilizing the fish offal did not appear to be profitable except for the largest freezer trawlers. However, if the vessels were changed with the dual objective of increasing the yield of the main products the economic benefits could be quite significant. This means making more space on board for installing processing equipment that leads to improved yields for the mains products while at the same time making it possible to process and store the by products. The necessary investment was estimated to pay off in three years (Rikhardsson, 1992).

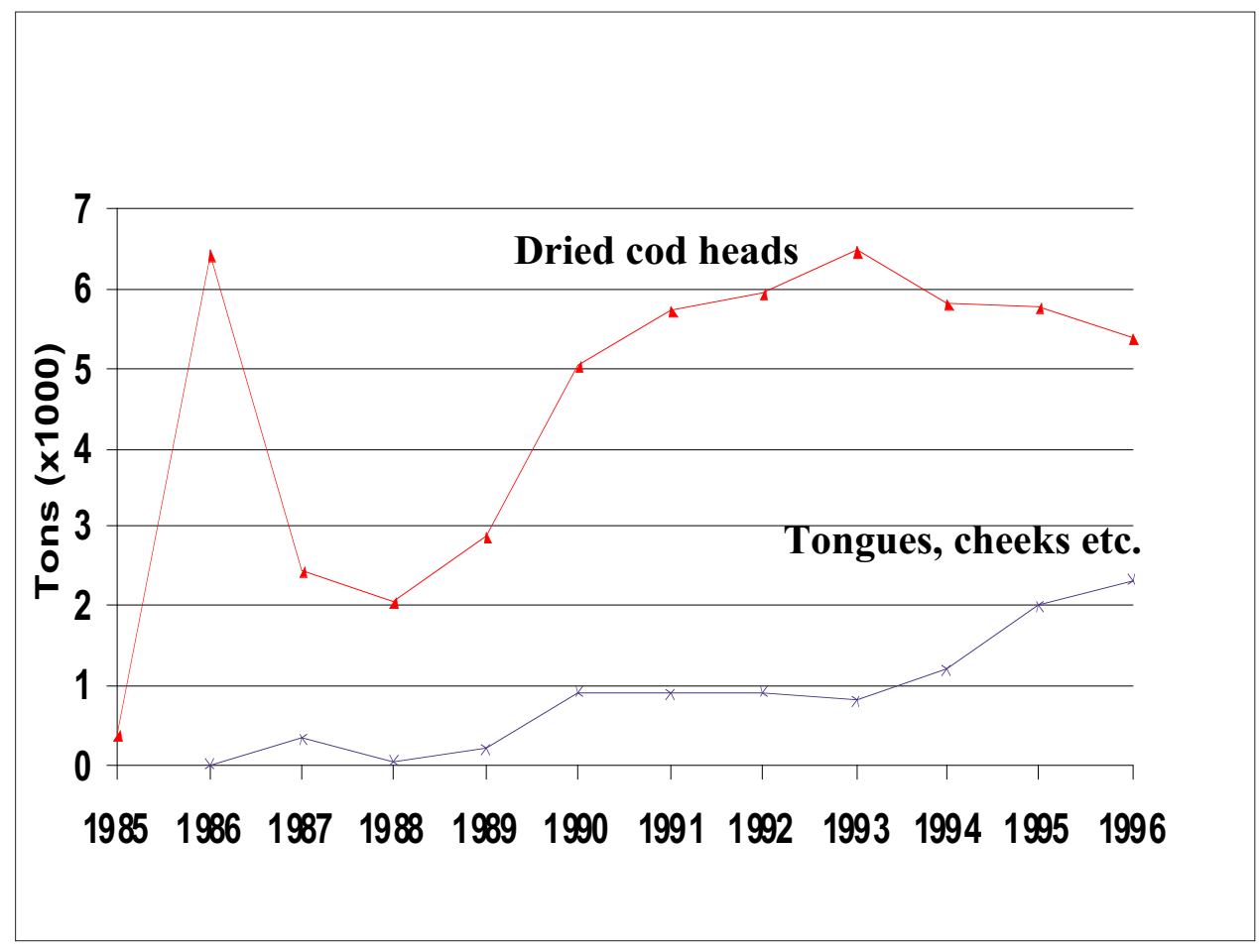

Fig. 15. Export of fish head products (Fikifelag Islands, 1994-96).

\section{The Future}

Modern fishery science and advanced harvesting policies will gradually change the perception of capture fisheries from hunting a wild pray into mariculture and harvesting. This will only happen when we know enough about the population dynamics, the recruitment etc. to evoke confidence in the data. But obviously, the determinant factor for all development in the sector depends on the operational framework made and how the fisheries are controlled. The ITQ system in Iceland appears to be basically working and it has set a new stage for the whole industry. It can probably best be described as turning the industry from a resource or quantity orientation to that of more value and profitability. The term "tragedy of the com- 
mon" is well known. It implies competition to get as much as possible in as short time as possible. It also implies that responsibility of the resource is somebody else's problem. The fish processing industry is thus very dependent on the fisheries policies that are in place and how the fisheries are controlled. Effort quotas combined with limitations of e.g. engine sizes of vessels actually can impair the economy of the fishing operations.

From the food processing point of view, few food items are as difficult to deal with as fish. New highly advanced technologies are making it possible to reduce costs and ensure better quality of products. Information systems are already at hand which can provide data showing when and how it is best to capture the fish from the value point of view. Markets are being linked together in a way that enables the fishermen and processors to take intelligent decisions regarding harvesting, processing and marketing.

The biggest challenge to capture fisheries today is environmental concerns and these cannot be ignored. The consumer wants assurances that the natural resources are being utilized in a sustainable sensible manner. This relates to fisheries science, fisheries polices and control. Traceability will be very important and will only be solved with relatively advanced information systems. This means that the "whole story" of the fish products is recorded and can be made accessible. This also touches the processing side and utilization of the fish resources. It is totally unacceptable that one third of the fish from the capture fisheries worldwide are discarded at sea. Most of the discards are a potential raw material for processing, at least for much needed fishmeal. The cost of taking the by-catch on board is as high as taking the target species. Throwing away so much good fish protein is simply not acceptable. Perhaps the time has come to make it mandatory to bring the total catch ashore. There is no doubt that in the short run it would make fishing operations less profitable but in the long run the fish industry would find ways of processing this material in a profitable way. Developments in fish food technology will make it technologically and economically possible to produce quality products from all the raw material provided by capture fisheries.

\section{References}

ALVERSON, D. L., M. H. FREEBORG, S. A. MURAWSKI, and J. A. POPE. 1994. A global assessment of fisheries by-catch and discards. FAO Fish. Tech. Pap., No. 339, 233 p.

ANON. 1993. Samradshopur um baetta umgengni um audlindir sjavar. Reykjavik: Skyrsla, januar 1993. (Reykjavik: A report to the Ministry of Fisheries on improving the use of the marine resources).

1997. Hagnyting afla af Islandsmidum 1996. Aegir, 90(6), 14-17. (Utilization of Icelandic catches 1996).

ARNARSON, H., and K. KHODABANDEHLOO. 1993. Fish processing using computer vision and robots. In: Robotics in Meat, Fish and Poultry Processing, K. Khodabandehloo (ed). London, Glasgow, New York, Tokyo, Melbourne and Madras: Blackie Academic and Professional, p. 26-47.

ARNASON, H., H. P. THOKSTEINSSON and J. H. RIKHARDSSON. 1994. Aukin nyting fiskafla (improved utilization of catches). Icelandic Fisheries Laboratories: Report 34, 36 p.

ARNARSON, I. 1991. Flow lines for freezing plants. Thorgeir and Ellert Ltd., Akranes, Iceland: an internal report.

ARNASON, R. 1990. The Icelandic individual transferable quota system: a descriptive account. Marine Resource Economics, 8: 201-218.

BIRGISSON, R., and H. EYJOLFSDOTTIR. MS 1997. Nytingareftirlit fullvinnsluskipa. (Yield Control for Processing vessels). An unpublished report by the Icelandic Fisheries Laboratories.

BJARTMARZ, R. 1997. Traceability: the information flow from fishing to sale. Abstract. In: Information Technology in Fisheries and aquaculture. Proceedings of a seminar held in Reykjavik, April 29th, 1997. Reykjavik: Icelandic Fisheries Laboratories, IceTec and Union of Icelandic Fish Processors.

DANIELSSON, A. 1994. Productivity growth in the Icelandic fisheries and the natural resource. VIth EAFE Conference, Crete, 28-30 March 1994.

1997. Fishery management in Iceland. To be published in Ocean and Coastal Management by Elsevier Publishers.

FAO. 1995. Fisheries. In: World Agriculture Towards 2010: an FAO study. N. Alexandratos (ed.). FAO and John Wiley and Sons, p. 231-256.

1996. Quat. Bull. Stat., No. 9.

1997a. Reforming FAO; the challenge of world food security. FAO Circular.

1997b. FAO fisheries statistics, catches and landings 1995, Vol. 80. 
1997c. Aquaculture production statistics. Revision 9.

1997d. Review of the state of world fishery resources: marine fisheries. Fisheries Circular, No. 920.

FISKIFELAG ISLANDS. 1994, 1995 and 1996. Utvegur. Reykjavik: Fiskifelag Islands (Fishery Statistics: Reykjavik: Fisheries Association of Iceland).

GRETARSSON, H. 1994. Nyjir moguleikar sjofrystingar: Thorskafurdir a Bretlandsmarkad. Lokaverkefni. Thesis, University of Akureyri, $120 \mathrm{p}$.

GUDJONSSON, I. O. 1997. Connecting remote fishautions, buyers and sellers. Abstract. In: Information Technology in Fisheries and aquaculture. Proceedings of a seminar held in Reykjavik, April 29th, 1997. Reykjavik: Icelandic Fisheries Laboratories, IceTec and Union of Icelandic Fish Processors.

GUNNLAUGSSON, G. 1997. Vision technology: intelligent fish processing systems. In: Seafood from Producer to Consumer, Integrated Approach to Quality. Proceedings of the WEFTA Jubilee Conference, Holland 13th-16th November 1995, J. B. Luten, T. Borresen and J. Oehlenschlager (eds). Amsterdam, Lausanne, New York, Shannon, Singapore, Tokyo: Elsevier, p. 351-359.

HOLMES, S. 1997. Infomar: information and trading network for fresh fish. Abstract. In: Information Technology in Fisheries and Aquacuture. Proceedings of a seminar held in Reykjavik, April 29th, 1997. Reykjavik: Icelandic Fisheries Laboratories, IceTec and Union of Icelandic Fish Processors.

RIKHARDSSON, J. H. 1992. Vinnsluskip - fullnyting sjavarafla. (Processing vessels - full utilisation of the catch). Icelandic Fisheries Laboratories: Report 31, 52 p.

RIKHARDSSON, J. H, and R. BIRGISSON. 1995. Aflabot. Rannsoknaferd med Ljosafelli SU-70. (Improvement in fish handling on-board). Icelandic Fisheries Laboratories: Report 100, 24 p.

RIKHARDSSON, J. H., A. P. WENDEL, and R. BIRGISSON. 1996. Ferskfiskmarkadir. (Markets for Fresh Fish: Reykjavik: The Icelandic Fisheries Laboratories: an unpublished report ).

SHAW, D. 1993. Cutting fish by computer. Seafood Leader, July/August, 107-110.

SIGURGEIRSSON,G. B. 1995. Stjornkerfi fiskveida og gaedi landads afla: Ahrif mismunandi stjornkerfa fiskveida og aflamedferd. (Effect of different fisheries management regimes on fish quality). University of Iceland: M.Sc. Thesis, $136 \mathrm{p}$.

THORSTEINSSON, H. and G. VALDIMARSSON. 1995. Experimental utilization and marketing of by-catches and deep-water species in Iceland. In: Proceeding of the Deep Water Fisheries of the North Atlantic Ocean Slope, A.G. Hopper (ed.). Kluwer Academic Publishers, Holland, p. 377-384.

VALDIMARSSON. G. 1990. Utilization of selected fish by-products in Iceland: past and future. In: Proceedings of the International Conference on By-products, Anchorage, Alaska, 25-27 April, 1990, Sue Keller (ed.). Report No. 90-07, Alaska Sea Grant Collage Program, p. 71-78.

1992. Developments in fish processing-technological aspects of quality. In: Quality Assurance in the Fish Industry. Proceedings of the Jubilee Conference of the Technological Laboratory, Lyngby, Copenhagen, August 26-30, H. H. Huss, M. Jakobsen and J. Liston (eds.). Amsterdam, London, New York and Tokyo: Elsevier, p. $169-183$. 
